\title{
Effect of selective angiotensin antagonists on the antidiuresis produced by angiotensin-(1-7) in water-loaded rats
}

N.C.V. Baracho ${ }^{1}$ A.C. Simões-e-Silva ${ }^{1}$,

M.C. Khosla ${ }^{2}$ and

R.A.S. Santos ${ }^{1}$

\author{
${ }^{1}$ Laboratório de Hipertensão, Departamento de Fisiologia e Biofísica, \\ Instituto de Ciências Biológicas, U niversidade Federal de M inas Gerais, \\ Belo Horizonte, MG, Brasil \\ ${ }^{2}$ Department of Neuroscience, Cleveland Clinic Foundation, Cleveland, $\mathrm{OH}, \mathrm{USA}$
}

\section{Correspondence \\ R.A.S. Santos \\ Departamento de Fisiologia \\ e Biofísica, ICB, UFM G \\ Av. Antônio Carlos, 6627 \\ 31270-901 Belo Horizonte, M G \\ Brasil \\ Fax: 55 (031) 499-2924 \\ E-mail: marrob@ dedalus.Icc.ufmg.br \\ Presented at the II International Symposium on Vasoactive Peptides, O uro Preto, MG, Brasil, October 6-8, 1997. \\ Research supported by FAPEMIG, PRONEX, CNPq and CAPES. \\ N.C.V. Baracho and A.C. \\ Simões-e-Silva were recipients \\ of CNPq fellowships.}

Received April 7, 1998

Accepted May 4, 1998

\section{Abstract}

In the present study we evaluated the nature of angiotensin receptors involved in the antidiuretic effect of angiotensin-(1-7) (Ang-(1-7)) in water-loaded rats. Water diuresis was induced in male Wistar rats weighing 280 to $320 \mathrm{~g}$ by water load $(5 \mathrm{ml} / 100 \mathrm{~g}$ body weight by gavage). Immediately after water load the rats were treated subcutaneously with (doses are per $100 \mathrm{~g}$ body weight): 1) vehicle (0.05 $\mathrm{ml} 0.9 \%$ $\mathrm{NaCl}$ ); 2) graded doses of 20, 40 or 80 pmol Ang-(1-7); 3) $200 \mathrm{nmol}$ Losartan; 4) $200 \mathrm{nmol}$ Losartan combined with 40 pmol Ang-(1-7); 5) 1.1 or 4.4 nmol A-779; 6) $1.1 \mathrm{nmol} \mathrm{A-779} \mathrm{combined} \mathrm{with} \mathrm{graded}$ doses of 20, 40 or 80 pmol Ang-(1-7); 7) 4.4 nmol A-779 combined with graded doses of 20, 40 or 80 pmol Ang-(1-7); 8) 95 nmol CGP 42112A, or 9) 95 nmol CGP 42112A combined with 40 pmol Ang-(17). The antidiuretic effect of Ang-(1-7) was associated with an increase in urinary $\mathrm{Na}^{+}$concentration, an increase in urinary osmolality and a reduction in creatinine clearance $\left(\mathrm{C}_{\mathrm{Cr}}: 0.65 \pm 0.04 \mathrm{ml} / \mathrm{min} v \mathrm{~s}\right.$ $1.45 \pm 0.18 \mathrm{ml} / \mathrm{min}$ in vehicle-treated rats, $\mathrm{P}<0.05)$. A-779 and Losartan completely blocked the effect of Ang-(1-7) on water diuresis (2.93 $\pm 0.34 \mathrm{ml} / 60 \mathrm{~min}$ and $3.39 \pm 0.58 \mathrm{ml} / 60 \mathrm{~min}$, respectively). CGP 42112A, at the dose used, did not modify the antidiuretic effect of Ang-(1-7). The blockade produced by Losartan was associated with an increase in $\mathrm{C}_{\mathrm{Cr}}$ and with an increase in sodium and water excretion as compared with Ang-(1-7)-treated rats. When Ang-(1-7) was combined with A-779 there was an increase in $\mathrm{C}_{\mathrm{Cr}}$ and natriuresis and a reduction in urine osmolality compared with rats treated with Ang-(17) alone. The observation that both A-779, which does not bind to $\mathrm{AT}_{1}$ receptors, and Losartan blocked the effect of Ang-(1-7) suggests that the kidney effects of Ang-(1-7) are mediated by a non-AT $T_{1}$ angiotensin receptor that is recognized by Losartan.

\section{Key words}

- Renin-angiotensin system

- Angiotensin receptors

- Antidiuresis

- Losartan

- A-779

- Ang-(1-7) 


\section{Introduction}

The heptapeptide angiotensin-(1-7) (Ang(1-7)) is a recently identified active component of the renin-angiotensin system that can be formed by a route independent of angiotensin converting enzyme (1-3). Ang-(1-7) has been demonstrated in plasma and tissues of a variety of species, including man, dogs, sheep and rats (3-5).

In addition to the different enzymatic route for its generation, Ang-(1-7) differs importantly from Ang II by its selectivity. Although both peptides elicit some similar actions in the brain, such as changes in blood pressure (6-8) and an increase in neuronal activity (9), Ang-(1-7) is devoid of significant dipsogenic, vasoconstrictor or aldosterone secretagogue actions (see Ref. 2 for review). Ang-(1-7) can even present effects opposite to those of Ang II, such as those on the baroreceptor reflex sensitivity which is attenuated by Ang II and increased by Ang(1-7) (10).

A growing body of evidence suggests that one of the major physiological actions of Ang-(1-7) is related to the control of hydroelectrolyte balance. Dense immunostaining for Ang-(1-7) immunoreactivity has been demonstrated in the supraoptic and paraventricular nuclei of the hypothalamus and neurohypophysical (11), and Ang-(1-7) is as potent as Ang II in releasing AVP from hypothalamus-neurohypophysial explants (12). In addition, we have shown that Ang(1-7) possesses a potent peripheral antidiuretic activity in water-loaded rats that is not influenced by blockade of vasopressin $\mathrm{V}_{2}$ receptors $(13,14)$. In vitro, Ang-(1-7) has been reported to increase four-fold the hydraulic conductivity in intramedullary collecting ducts at a concentration of $10^{-9} \mathrm{~mol} / \mathrm{l}$ (14). In the proximal straight tubule Ang-(17) increases fluid and bicarbonate reabsorption at physiological concentrations $\left(10^{-12}\right.$ $\mathrm{mol} / \mathrm{l})(15)$.

In addition to water excretion, Ang-(1-7) appears to influence sodium handling by the kidneys. A natriuretic effect of supra-physiological doses of Ang-(1-7) has been reported in denervated kidneys (16) in vivo and in in situ perfused rat kidneys (17). The natriuretic effect of Ang-(1-7) in these preparations is in accordance with the observation that $10^{-9} \mathrm{~mol} / \mathrm{l}$ Ang-(1-7) inhibits $(20 \%) \mathrm{Na}^{+}$ flux in cultured renal tubular epithelial cells (18). A physiological role for Ang-(1-7) in the control of hydromineral balance is also suggested by the selective increase in its circulating levels in chronically salt-loaded rats (5). Moreover, the enzymes necessary to generate Ang-(1-7) from its precursors (Ang I or Ang II) are abundant in the kidney (19).

We have recently shown that the antidiuretic effect of Ang-(1-7) in water-loaded rats is completely blocked by the selective Ang-(1-7) antagonist A-779 (14,20). However, the effect of other selective angiotensin antagonists on the antidiuretic activity of this heptapeptide is not known. In this study we evaluated the nature of angiotensin receptors involved in the antidiuretic effect of Ang-(1-7) in water-loaded rats.

\section{Material and Methods}

\section{Animals}

Male Wistar rats weighing 280 to $320 \mathrm{~g}$ were used. The rats were housed in plastic cages with free access to ordinary chow and water, on a 14/10 h light/dark cycle.

\section{Effect of angiotensin antagonists on antidiuretic action of Ang-(1-7) in water-loaded rats}

Protocol 1: Effect of Losartan on the antidiuretic action of Ang-(1-7). Water diuresis was induced by water load $(5 \mathrm{ml} / 100$ g body weight by gavage). Immediately after the water load, the animals were treated subcutaneously with vehicle $(0.05 \mathrm{ml} 0.9 \%$ $\mathrm{NaCl} / 100$ g body weight, $\mathrm{N}=27), 200 \mathrm{nmol}$ 
Losartan/100 g body weight ( $\mathrm{N}=15), 40$ pmol Ang-(1-7)/100 g body weight $(\mathrm{N}=32)$ or $200 \mathrm{nmol}$ Losartan/100 $\mathrm{g}$ body weight associated with 40 pmol Ang-(1-7)/100 g body weight $(\mathrm{N}=24)$. Urine volume was collected for $60 \mathrm{~min}$ after water loading.

Protocol 2: Effect of A-779 on the antidiuretic action of Ang-(1-7). Immediately after the water load rats were treated subcutaneously with 1) Ang-(1-7) alone, $20(\mathrm{~N}=6), 40$ $(\mathrm{N}=27)$ or $80 \mathrm{pmol} / 100 \mathrm{~g}$ body weight $(\mathrm{N}=$ 6); 2) A-779 alone, $1.1(\mathrm{~N}=18)$ or $4.4 \mathrm{nmol} /$ $100 \mathrm{~g}$ body weight $(\mathrm{N}=14)$; 3) $1.1 \mathrm{nmol} \mathrm{A-}$ $779 / 100 \mathrm{~g}$ body weight combined with different doses of Ang-(1-7) $(20(\mathrm{~N}=6), 40(\mathrm{~N}$ $=10)$ and $80 \mathrm{pmol} / 100 \mathrm{~g}$ body weight $(\mathrm{N}=$ 6)), or 4) $4.4 \mathrm{nmol} \mathrm{A-779/100} \mathrm{g} \mathrm{body} \mathrm{weight}$ combined with graded doses of Ang-(1-7) $(20(\mathrm{~N}=6), 40(\mathrm{~N}=9)$ and $80 \mathrm{pmol} / 100 \mathrm{~g}$ body weight $(\mathrm{N}=6))$. Urine volume was collected and measured $60 \mathrm{~min}$ after water loading.

Protocol 3: Effect of CGP 42112A on the antidiuretic action of Ang-(1-7). Immediately after the water load rats were treated subcutaneously with $95 \mathrm{nmol}$ CGP 42112A/ $100 \mathrm{~g}$ body weight $(\mathrm{N}=8)$ or $95 \mathrm{nmol}$ CGP 42112A/100 g body weight combined with 40 pmol Ang-(1-7)/100 g body weight $(\mathrm{N}=$ $24)$. Urine volume was collected and measured 60 min after water loading.

\section{Mechanism involved in the blockade of the antidiuretic action of Ang-(1-7) in water-loaded rats}

Protocol 1: Effect of Losartan on renal function parameters. Immediately after water loading, other groups of animals were treated subcutaneously with vehicle $(0.05$ $\mathrm{ml} 0.9 \% \mathrm{NaCl} / 100 \mathrm{~g}$ body weight, $\mathrm{N}=17$ ), 40 pmol Ang-(1-7)/100 g body weight $(\mathrm{N}=$ 16), $200 \mathrm{nmol}$ Losartan/100 g body weight $(\mathrm{N}=9)$ or $200 \mathrm{nmol}$ Losartan/100 g body weight associated with 40 pmol Ang-(1-7)/ $100 \mathrm{~g}$ body weight $(\mathrm{N}=10)$ and transferred to metabolic cages. Blood and urine samples for the measurement of creatinine clearance $\left(\mathrm{C}_{\mathrm{Cr}}\right)$, osmolality, and sodium concentration were collected $60 \mathrm{~min}$ after water loading.

Protocol 2: Effect of A-779 on renal function parameters. Immediately after water loading, additional groups of rats were treated subcutaneously with $4.4 \mathrm{nmol} \mathrm{A-779/100} \mathrm{g}$ body weight $(\mathrm{N}=9)$ or $4.4 \mathrm{nmol} \mathrm{A}-779 / 100$ $\mathrm{g}$ body weight combined with $40 \mathrm{pmol}$ Ang$(1-7) / 100$ g body weight $(\mathrm{N}=10)$ and transferred to metabolic cages. Blood and urine samples for measurement of $\mathrm{C}_{\mathrm{Cr}}$, osmolality, and sodium concentration were collected 60 min after water loading.

\section{General procedures}

Blood sampling. Immediately after urine collection, the rats were anesthetized with ether and blood samples were withdrawn by heart puncture. Blood samples were kept for $30 \mathrm{~min}$ at room temperature and then centrifuged at $2000 \mathrm{rpm}$ for $10 \mathrm{~min}$. Serum was used for measurement of serum osmolality, $\mathrm{Na}^{+}$and creatinine concentration.

Urine samples. After collection, the urine samples were centrifuged at $3000 \mathrm{rpm}$ for 5 min (room temperature) for measurement of urine osmolality, $\mathrm{Na}^{+}$and creatinine concentration.

\section{Analytical procedures}

Sodium was measured by flame photometry (Corning 400, Corning Inc., New York, NY). Serum and urine osmolality were measured using a freezing-point Osmometer (Fiske Associates, Norwood, MA). Creatinine clearance measurements were performed using a kit which minimizes the interference of endogenous chromogens (cat. 35E, Labtest, Belo Horizonte, MG).

\section{Chemicals}

The nonpeptide $\mathrm{AT}_{1}$ receptor antagonist, Losartan (molecular mass $=461$ ), was a gift 
Figure 1 - Effect of Losartan on the antidiuretic action of Ang-(17). Immediately after water load, rats were treated subcutaneously with vehicle (saline, $N=27$ ), 200 nmol Losartan/100 $\mathrm{g}$ body weight ( $\mathrm{N}=15), 40 \mathrm{pmol}$ Ang-(1-7)/100 g body weight ( $\mathrm{N}=32$ ) or $200 \mathrm{nmol}$ Losartan/100 g body weight combined with 40 pmol Ang-(1-7)/100 $\mathrm{g}$ body weight $(\mathrm{N}=24)$. Urine was collected $60 \mathrm{~min}$ after water loading. Data are reported as means \pm SEM. $* P<0.05$ compared with saline-treated group (ANOVA followed by the Newman-Keuls test).

Figure 2 - Effect of A-779 on the antidiuretic action of Ang-(1-7). Immediately after water load, rats were treated subcutaneously with vehicle (saline, $\mathrm{N}=$ 27); graded doses of Ang-(1-7) alone, $20(\mathrm{~N}=6), 40(\mathrm{~N}=27)$ and $80 \mathrm{pmol} / 100 \mathrm{~g}$ body weight $(\mathrm{N}=$ 6); $1.1 \mathrm{nmol} \mathrm{A}-779 / 100 \mathrm{~g}$ body weight ( $\mathrm{N}=18) ; 4.4 \mathrm{nmol}$ A-779/ $100 \mathrm{~g}$ body weight $(\mathrm{N}=14) ; 1.1$ nmol A-779/100 g body weight combined with graded doses of Ang-(1-7) $(20(\mathrm{~N}=6), 40(\mathrm{~N}=10)$ and $80 \mathrm{pmol} / 100 \mathrm{~g}$ body weight $(\mathrm{N}=6))$; or $4.4 \mathrm{nmol} \mathrm{A}-779 / 100 \mathrm{~g}$ body weight combined with graded doses of Ang-(1-7) (20 ( N $=6), 40(\mathrm{~N}=9)$ and $80 \mathrm{pmol} / 100$ $\mathrm{g}$ body weight $(\mathrm{N}=6))$. Urine was collected 60 min after water loading. Data are reported as means \pm SEM. $* P<0.05$ compared with saline-treated group (ANOVA followed by the Newman-Keuls test)
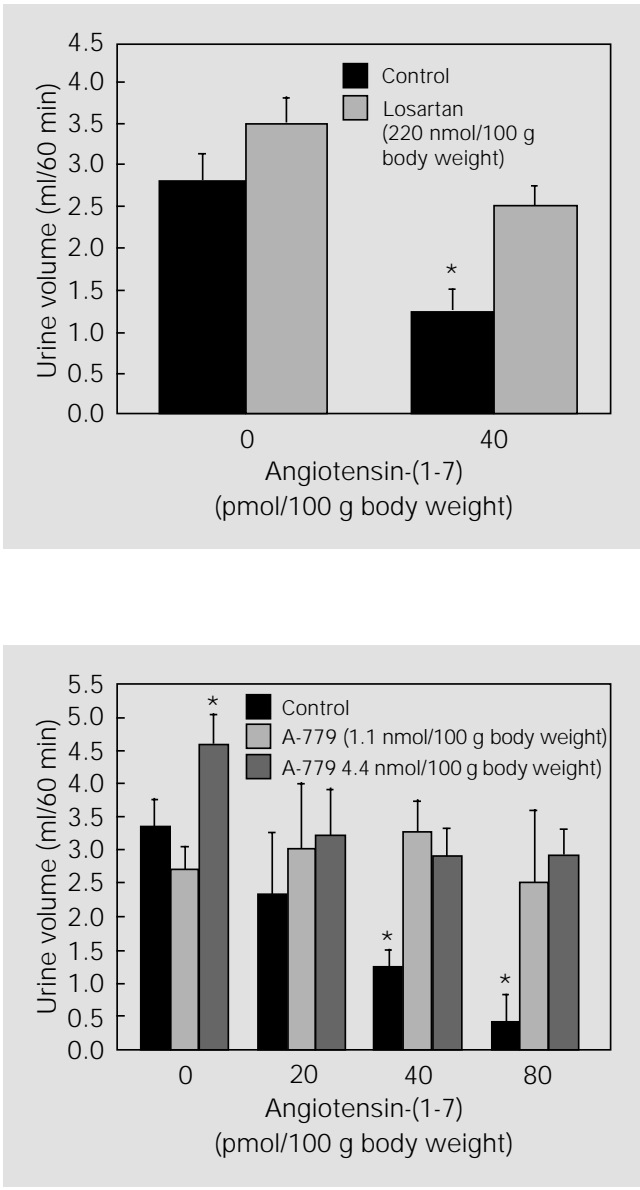

from Du Pont de Nemours \& Company (Wilmington, $\mathrm{DE}$ ) and the $\mathrm{AT}_{2}$ receptor antagonist, CGP 42112A (molecular mass = 1053), was provided by Ciba-Geigy Limited (Basel, Switzerland). The Ang-(1-7) analogue, A-779 (molecular mass = 873.1), was synthesized by Dr. M.C. Khosla (Cleveland Clinic Foundation). Ang-(1-7) (molecular mass $=890$ ) was synthesized by Dr. M.C. Khosla or obtained from Bachem (Batch \# 25691; Torrance, CA). All other chemicals used were of the highest purity available.

\section{Statistical analysis}

All results are reported as means \pm SEM. Data were analyzed using one-way analysis of variance (ANOVA) followed by the Newman-Keuls test. The level of significance was set at $\mathrm{P}<0.05$.

\section{Results}

\section{Effect of angiotensin antagonists on the antidiuretic action of Ang-(1-7) in water-loaded rats}

Blockade of the antidiuretic effect of Ang(1-7). As shown in Figure 1, Losartan completely blocked the antidiuretic effect of Ang(1-7) in water-loaded rats. Losartan alone, at the dose used, did not change water diuresis compared to vehicle-treated rats.

The effect of the two doses of A-779 (1.1 and $4.4 \mathrm{nmol} / 100 \mathrm{~g}$ body weight) on the antidiuretic action of graded doses of Ang(1-7) (20 to $80 \mathrm{pmol} / 100 \mathrm{~g}$ body weight) is shown in Figure 2. A-779 completely blocked the antidiuretic effect of Ang-(1-7) in waterloaded rats at both doses used. A-779 given alone produced an increase in water diuresis compared with vehicle-treated rats at the highest dose ( $4.4 \mathrm{nmol} / 100 \mathrm{~g}$ body weight).

As shown in Figure 3, the $\mathrm{AT}_{2}$ ligand, CGP 42112A, did not change water diuresis or the antidiuretic effect of Ang-(1-7) in water-loaded rats.

\section{Mechanisms involved in the blockade of the antidiuretic action of Ang-(1-7) in water-loaded rats}

Effect of Losartan on renal function parameters. The effect of Losartan on renal function parameters in water-loaded rats is shown in Table 1. Losartan blockade of the antidiuretic effect of Ang-(1-7) was associated with a significant increase in creatinine clearance and in sodium and water excretion compared with Ang-(1-7)-treated rats $(\mathrm{P}<0.05)$.

Effect of A-779 on renal function parameters. The effect of A-779 on renal function parameters in water-loaded rats is shown in Table 1. The increase in water diuresis produced by A-779 given alone was associated with a decrease in urine osmolality and natriuresis and an increase in creatinine clear- 
ance compared with vehicle-treated rats. The results obtained with the combination of A779 and Ang-(1-7) did not differ from those obtained with A-779 alone.

\section{Discussion}

We have previously shown that the antidiuretic effect of Ang-(1-7) in water-loaded rats was completely blocked by the Ang-(17) selective antagonist, A-779 $(14,20)$. In the present study we extended this observation by showing that Losartan, an $\mathrm{AT}_{1}$ receptor antagonist, also blocked the antidiuretic effect of Ang-(1-7) in water-loaded rats.

The antidiuretic effect of Ang-(1-7) in water-loaded rats was associated with a decrease in creatinine clearance and an increase in water reabsorption. Both A-779 and Losartan blocked the antidiuretic effect by preventing the changes in creatinine clearance and in sodium and water excretion produced by Ang-(1-7).

Our observation that Losartan blocked the antidiuretic effect of Ang-(1-7) is consistent with other studies. Garcia and Garvin (15) found that the effects of Ang-(1-7) on fluid and bicarbonate absorption in isolated

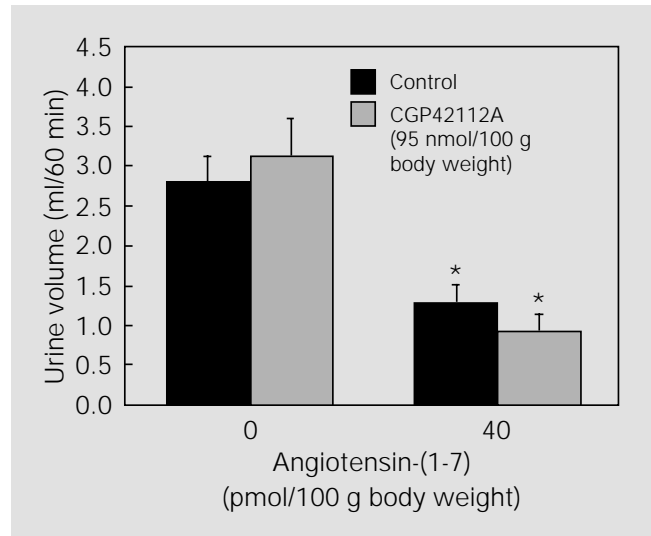

proximal straight tubules were blocked by Losartan. A partial blockade of the effect of Ang-(1-7) on $\mathrm{O}_{2}$ consumption in rat proximal tubules was also observed by Handa et al. (16). Similar findings were obtained in the heart by Gironacci et al. (21). These data raised two possible explanations: 1) Ang-(17) may act through $\mathrm{AT}_{1}$ receptors or 2) Losartan can block a subtype of Ang-(1-7) receptor. The first explanation is unlikely since Ang-(1-7) does not exert most of the Ang II actions that are mediated through $\mathrm{AT}_{1}$ receptors, i.e., vasoconstriction and induction of drinking (4) and Ang-(1-7) binds poorly to $\mathrm{AT}_{1}$ receptors $(3,20)$. The second
Figure 3 - Effect of CGP 42112A on the antidiuretic action of Ang(1-7). Immediately after water load, rats were treated subcutaneously with vehicle (saline, $\mathrm{N}=$ 27), 40 pmol Ang-(1-7)/100 g body weight $(\mathrm{N}=32), 95 \mathrm{nmol}$ CGP 42112A/100 g body weight $(\mathrm{N}=8)$ or $95 \mathrm{nmol}$ CGP 42112A/ $100 \mathrm{~g}$ body weight combined with 40 pmol Ang-(1-7)/100 g body weight $(\mathrm{N}=24)$. Urine was collected $60 \mathrm{~min}$ after water loading. Data are reported as means \pm SEM. $* P<0.05$ compared with saline-treated group (ANOVA followed by the Newman-Keuls test).

Table 1 - Effect of angiotensin antagonists on renal function parameters in water-loaded rats.

Immediately after water loading, rats were treated subcutaneously with vehicle (Control, $0.05 \mathrm{ml} 0.9 \% \mathrm{NaCl} / 100 \mathrm{~g}$ body weight), Ang-(1-7) (40 $\mathrm{pmol} / 100 \mathrm{~g}$ body weight), A-779 (4.4 nmol/100 g body weight) or A-779 (4.4 nmol/100 g body weight) combined with Ang-(1-7) (40 pmol/100 g body weight), and transferred to metabolic cages. Data are reported as means $\pm \mathrm{SEM}$. $* \mathrm{P}<0.05$ compared with Ang-(1-7)-treated rats (ANOVA followed by the Newman-Keuls test). $+\mathrm{P}<0.05$ compared with the control group (ANOVA followed by the Newman-Keuls test). Osm $=$ Osmolality, $\mathrm{C}_{\mathrm{Osm}}=$ osmolal clearance and $\mathrm{C}_{\mathrm{Cr}}=$ creatinine clearance.

\begin{tabular}{|c|c|c|c|c|c|c|}
\hline Parameter & $\begin{array}{l}\text { Control } \\
(\mathrm{N}=17)\end{array}$ & $\begin{array}{l}\text { Ang-(1-7) } \\
(\mathrm{N}=16)\end{array}$ & $\begin{array}{l}\text { A-779 } \\
(\mathrm{N}=9)\end{array}$ & $\begin{array}{c}\text { A-779 + Ang-(1-7) } \\
(\mathrm{N}=10)\end{array}$ & $\begin{array}{l}\text { Losartan } \\
(\mathrm{N}=9)\end{array}$ & $\begin{array}{c}\text { Losartan + Ang(1-7) } \\
(\mathrm{N}=10)\end{array}$ \\
\hline Urine volume, $\mathrm{ml} / 60 \mathrm{~min}$ & $3.0 \pm 0.1^{*}$ & $1.51 \pm 0.13^{+}$ & $3.4 \pm 0.32 *$ & $4.25 \pm 0.43^{*+}$ & $3.11 \pm 0.31^{*}$ & $3.20 \pm 0.23^{*}$ \\
\hline Serum Osm, mOsm/kg & $300.6 \pm 2.9^{*}$ & $283.5 \pm 3.7$ & $293.4 \pm 2.0^{*}$ & $290.6 \pm 4.1^{*}$ & $300.7 \pm 3.4^{*}$ & $299.9 \pm 2.3^{*}$ \\
\hline Urinary Osm, mOsm/kg & $167.6 \pm 9.3^{*}$ & $278.8 \pm 32.1$ & $140.3 \pm 12.9^{*}$ & $125.4 \pm 18.5^{*}$ & $140.0 \pm 13.3^{*}$ & $143.9 \pm 12.5^{*}$ \\
\hline $\mathrm{C}_{\mathrm{Osm}}, \mathrm{ml} / \mathrm{min}$ & $0.029 \pm 0.002$ & $0.027 \pm 0.003$ & $0.026 \pm 0.002$ & $0.028 \pm 0.003$ & $0.024 \pm 0.003$ & $0.027 \pm 0.003$ \\
\hline Water excretion, $\mathrm{ml} / \mathrm{min}$ & $0.023 \pm 0.002 *$ & $0.002 \pm 0.002^{+}$ & $0.031 \pm 0.005^{*}$ & $0.040 \pm 0.007^{*}$ & $0.028 \pm 0.003^{*}$ & $0.028 \pm 0.003^{*}$ \\
\hline $\mathrm{C}_{\mathrm{Cr}}, \mathrm{ml} / \mathrm{min}$ & $1.45 \pm 0.18^{*}$ & $0.65 \pm 0.04^{+}$ & $1.44 \pm 0.14^{*}$ & $1.62 \pm 0.17 *$ & $1.45 \pm 0.16^{*}$ & $1.50 \pm 0.10^{*}$ \\
\hline Serum $\left[\mathrm{Na}^{+}\right], \mathrm{mEq} / \mathrm{l}$ & $138 \pm 1.5^{*}$ & $126.3 \pm 1.2^{+}$ & $140 \pm 1^{*}$ & $140 \pm 1^{*}$ & $141 \pm 1^{*}$ & $141 \pm 1^{*}$ \\
\hline Urinary $\left[\mathrm{Na}^{+}\right], \mathrm{mEq} / \mathrm{l}$ & $17.9 \pm 0.9 *$ & $30.3 \pm 3.2^{+}$ & $18.2 \pm 1.0^{*}$ & $17.5 \pm 1.5^{*}$ & $17.2 \pm 1.6^{*}$ & $18.7 \pm 1.3^{*}$ \\
\hline $\mathrm{Na}^{+}$excreted, $\mathrm{mEq}$ & $0.054 \pm 0.002^{*}$ & $0.043 \pm 0.003^{+}$ & $0.061 \pm 0.004 *$ & $0.068 \pm 0.005^{*}$ & $0.052 \pm 0.004 *$ & $0.059 \pm 0.005^{*}$ \\
\hline
\end{tabular}


possibility is more likely because it is reasonable to conceive that the still unidentified renal Ang-(1-7) receptor(s) can resemble $\mathrm{AT}_{1}$ receptors and that Losartan can bind to it (them). This second possibility was also substantiated by recent observations that have raised concerns about the specificity of Losartan (22-24). It was shown that this compound can bind to non-angiotensin II binding sites (22) or interfere with non-angiotensin-mediated responses (23). In addition, differential regulation of Ang II and Losartan binding sites was observed in rat glomeruli and human mesangial cells (24). The recent observation that Losartan can block thromboxane $\mathrm{A}_{2}$ receptors further indicates a lack of specificity of this angiotensin $\mathrm{AT}_{1}$ receptor ligand (25).

The finding that both Losartan and A779 can block the antidiuretic effect of Ang(1-7) suggests the existence of at least two subtypes of Ang-(1-7) receptors: one which is expressed, for example, in blood vessels (26) and the brain (rostral ventrolateral medulla and caudal pressor area) $(10,20)$ and is not blocked by $\mathrm{AT}_{1}$ or $\mathrm{AT}_{2}$ antagonists
$(10,20)$, and the other expressed at sites such as the hypothalamus (27), heart (21) and the kidney (15) which can be blocked by Losartan and to a variable extent by $\mathrm{AT}_{2}$ ligands. Nevertheless, the observation that Losartan can block at least some of the Ang-(1-7) effects on the kidney raises the intriguing possibility that blockade of endogenous Ang(1-7) can contribute to its pharmacological effects.

Administration of A-779 alone at a dose of $4.4 \mathrm{nmol} / 100 \mathrm{~g}$ body weight increased water diuresis, suggesting that even in this condition, unlike vasopressin, whose plasma levels are suppressed (28), endogenous Ang(1-7) can modulate water excretion. However, an agonistic effect of A-779 at this dose or a synergistic effect with other peptides, although unlikely, cannot be ruled out.

\section{Acknowledgments}

We are thankful to José R. Silva and Soraia S. Silva for skillful technical assistance.

\section{References}

1. Ferrario $\mathrm{CM}$, Barnes $\mathrm{KL}$, Block $\mathrm{CH}$, Brosnihan KB, Diz DI, Khosla M C \& Santos RAS (1990). Pathways of angiotensin formation and function in the brain. Hypertension, 15: I-13-I-19.

2. Santos RAS \& Campagnole-Santos MJ (1994). Central and peripheral actions of angiotensin-(1-7). Brazilian J ournal of Medical and Biological Research, 27: 1033-1047.

3. Santos RAS, Brosnihan KB, Chappell MC, Pesquero J L, Chernicky CL, Greene LJ \& Ferrario CM (1988). Converting enzyme activity and angiotensin metabolism in the dog brainstem. Hypertension, 11: 153157.

4. Santos RAS, Brosnihan KB, J acobsen DW, DiCorleto PE \& Ferrario CM (1992). Production of angiotensin-(1-7) by human vascular endothelium. Hypertension, 19 (Suppl II): II-56-II-61.

5. Botelho LM, Block $\mathrm{CH}$, Khosla MC \& Santos RAS (1994). Plasma angiotensin-
(1-7) level is increased by water deprivation, salt load and hemorrhage. Peptides, 15: 723-729.

6. Campagnole-Santos MJ, Diz DI, Santos RAS, Khosla MC, Brosnihan KB \& Ferrario CM (1989). Cardiovascular effects of angiotensin (1-7) microinjected into the dorsal medulla of rats. American J ournal of Physiology, 257: H324-H329.

7. Silva LCS, Fontes MAP, CampagnoleSantos MJ, Khosla MC, Campos J r RR, Guertzenstein PG \& Santos RAS (1993). Cardiovascular effects produced by microinjection of angiotensin-(1-7) on vasopressor and vasodepressor sites of the ventrolateral medulla. Brain Research, 613: 321-325.

8. Fontes MAP, Silva LCS, CampagnoleSantos MJ , Khosla MC, Guertzenstein PG \& Santos RAS (1994). Evidence that angiotensin-(1-7) plays a role in the central control of blood pressure at the ventrolateral medulla acting through specific re- ceptor. Brain Research, 665: 175-180.

9. Felix D, Khosla MC, Imbodem H, Montani B \& Ferrario CM (1991). Neurophysiological responses to angiotensin-(1-7). Hypertension, 17: 1111-1114.

10. Campagnole-Santos MJ, Heringer SB, Batista EN, Khosla MC \& Santos RAS (1992). Differential baroreceptor reflex modulation by centrally infused angiotensin peptides. American J ournal of Physiology, 263: R89-R94.

11. Block $\mathrm{CH}$, Santos RAS, Brosnihan $\mathrm{KB} \&$ Ferrario CM (1988). Immunocytochemical localization of angiotensin (1-7) in the rat forebrain. Peptides, 9: 1395-1401.

12. Schiavone MT, Santos RAS, Brosnihan KB, Khosla MC \& Ferrario CM (1988). Release of vasopressin from the rat hypothalamo-neurohypophysial system by angiotensin-(1-7) heptapeptide. Proceedings of the National Academy of Sciences, USA, 85: 4095-4098.

13. Santos RAS \& Baracho NCV (1992). An- 
giotensin-(1-7) is a potent antidiuretic peptide in rats. Brazilian J ournal of Medical and Biological Research, 25: 651-654.

14. Santos RAS, Simões e Silva AC, Magaldi AJ , Cesar KR, Passaglio KT \& Baracho NCV (1996). Evidence for a physiological role of angiotensin-(1-7) in the control of hydroelectrolyte balance. Hypertension, 27: 875-884.

15. Garcia NH \& Garvin JL (1994). Angiotensin-(1-7) has a biphasic effect on fluid absorption in the proximal straight tubule. J ournal of the American Society of Nephrology, 5: 1133-1138.

16. Handa RK, Ferrario CM \& Strandhoy J W (1996). Renal actions of angiotensin-(1-7): in vivo and in vitro studies. American J ournal of Physiology, 270 (Renal Fluid and Electrolyte Physiology, 39): F141-F147.

17. Dellipizzi A, Hilchley SD, McGiff JC\& Bellquilley CP (1994). Natriuretic action of angiotensin-(1-7). British J ournal of Pharmacology, 111: 1-4.

18. Andreatta-Van Leyen S, Romero MF, Khosla MC \& Douglas J G (1993). Modulation of phospholipase $A_{2}$ activity and sodium transport by angiotensin-(1-7). Kidney International, 44: 932-936.

19. Erdös EG \& Skiedgel RA (1990). Renal metabolism of angiotensin I and II. Kidney International, 38: 24-27.
20. Santos RAS, Campagnole-Santos MJ, Baracho NCV, Fontes MAP, Silva LCS, Neves LAA, Oliveira DR, Caligiorne SM, Rodrigues ARV, Gropen J r C, Carvalho WS, Simões e Silva $A C$ \& Khosla MC (1994). Characterization of a new angiotensin antagonist selective for angiotensin-(1-7): Evidence that the actions of angiotensin-(1-7) are mediated by specific angiotensin receptors. Brain Research Bulletin, 35: 293-298.

21. Gironacci MM, Adler-Graschinsky E, Peña $C \&$ Enero MA (1994). Effects of angiotensin II and angiotensin-(1-7) on the release of $\left[{ }^{3} \mathrm{H}\right]$ norepinephrine from rat atria. Hypertension, 24: 457-460.

22. Widdowson PS, Renouard A \& Vilaine J (1993). Binding of $\left[{ }^{3} \mathrm{H}\right]$ angiotensin II and [ $\left.{ }^{3} \mathrm{H}\right]$ DuP 753 (Losartan) to rat liver homogenates reveals multiple sites. Relationship to $A T_{1 a}$ - and $A T_{1 b}$-type angiotensin receptors and novel nonangiotensin binding sites. Peptides, 14: 829-837.

23. Averill DB, Tsuchihashi T, Khosla MC \& Ferrario CM (1994). Losartan, nonpeptide angiotensin II-type 1 ( $\mathrm{AT}_{1}$ ) receptor antagonist attenuates pressor and sympathoexcitatory responses evoked by angiotensin II and L-glutamate in rostral ventrolateral medulla. Brain Research, 665: 245252.
24. Chansel $D$, Bizet $T$, Vandermeersch $S$, Pham P, Levy B \& Ardaillou R (1994). Differential regulation of angiotensin II and losartan binding sites in glomeruli and mesangial cells. American J ournal of Physiology, 266: F384-F393.

25. Li P, Ferrario CM \& Brosnihan KB (1997). Nonpeptide angiotensin II antagonist Losartan inhibits thromboxane $\mathrm{A}_{2}$-induced contractions in canine coronary arteries. J ournal of Pharmacology and Experimental Therapeutics, 281: 1065-1070.

26. Pörsti I, Bara AT, Busse R \& Hecker M (1994). Release of nitric oxide by angiotensin-(1-7) from porcine coronary endothelium: implications for a novel angiotensin receptor. British J ournal of Pharmacology, 111: 652-654.

27. Ambühl $P$, Felix $D$, Imboden $H$, Khosla MC \& Ferrario CM (1992). Effects of angiotensin analogues and angiotensin receptor antagonists on paraventricular neurones. Regulatory Peptides, 38: 111-120.

28. Robertson GL (1985). Osmoregulation of thirst and vasopressin secretion: functional properties and their relationship to water balance. In: Schrier RW (Editor), Vasopressin. Raven Press, New York, 203-212. 